\title{
Intraspecific genetic variation in gastropods Liobaikalia stiedae (Dybowski, 1875) in Baikal
}

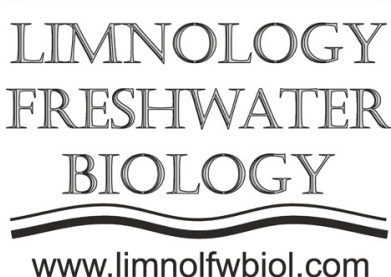

\author{
Kovalenkova M.V. ${ }^{1 *}$, Sitnikova T.Ya. ${ }^{1}$, Sherbakov D.Yu. ${ }^{1,2}$ \\ ${ }^{1}$ Limnological Institute, Siberian Branch of the Russian Academy of Sciences, Ulan-Batorskaya Str., 3, Irkutsk, 664033, Russia \\ ${ }^{2}$ Irkutsk State University, Karl Marx Str., 1, Irkutsk, 664003, Russia
}

\begin{abstract}
Genetic variation of Baikal endemic gastropods Liobaikalia stiedae was analyzed using the nucleotide sequence of the COI mitochondrial gene fragment. High intraspecific mtDNA differentiation is revealed, while local populations can be more similar to related species than to other populations.
\end{abstract}

Keywords: sand-dwelling, Baicaliidae, gene flow

\section{Introduction}

Intraspecific diversity sheds light on scales and mechanisms of the geographic and ecological isolation in speciation. The prosobranch snail family Baicaliidae includes more than 40 species. It is the largest endemic molluscan group of Lake Baikal. Some species widely distributed in the lake; the habitat of a few species is limited to a single geographical part (northern or southern) of the lake. Baicaliids are found on all types of sediments in different macro- and microhabitats. "Southern" Liobaikalia stiedae (Dybowski, 1875) burrows in soft substrates and lays eggs on sand grains. Thereby viscous population structure of this species can be expected. Previous study using mitochondrial DNA sequences indicated that the monotypic genus Liobaikalia was low genetically differentiated from related genera Korotnewia and Parabaikalia $(<1 \%$ of nucleotide substitutions at Folmer region) (Zubakov et al., 1997; Kovalenkova et al., 2015). Observed discrepancies between the species tree and current taxonomy of the group were explained by fast morphological evolution in the Baicaliidae family (Kovalenkova et al., 2015).

\section{Material and methods}

Ten specimens of $L$. stiedae were collected from three locations in the South Baikal basin with dredging (13-45 m). We used universal primers for amplification and sequencing fragments of the mitochondrial gene COI (Folmer et al. 1994). The best-fit model of sequence evolution was inferred based on the Bayesian information criterion with IQ-tree v. 1.6.10 (Nguyen et al., 2014). Medians of paired interspecific and interlocal genetic distances were estimated with the HKY model for COI in the "ape" package R (Paradis et al, 2004). To estimate divergence times of $L$. stiedae haplotypes and related baicaliids, we used earlier suggested divergence rate of the "Folmer region" $1.83 \% \pm 0.21 / \mathrm{Myr}$ for hydrobioid gastropods (Wilke, 2003). The phylogenetic tree was reconstructed based on unique haplotypes of the COI gene from $L$. stiedae and closely related species using BEAST v. 1.8.4 (Drummond and Rambaut, 2007). Haplotypes of Baicalia carinata and Maackia herderiana were used as outgroups. The different combinations of the speciation models were used for the analysis: Yule or birth-death process with strict clock or uncorrelated lognormal relaxed clock.

\section{Results and discussion}

A total of 4 unique CO haplotypes was detected. Every local population had one (Koty, Posolskaya bank) or two haplotypes (Babushkin). Median genetic distances between local populations ranged from 1.8 to $3.9 \%$ of nucleotide substitutions. Genetic distance is highest between COI haplotypes from Babushkin and Koty ( $>3.5 \%$ substitutions), whereas median interspecific variation for baicaliids is ab. $5 \%$.

The phylogenetic reconstructions have indicated speciation birth-death process with relaxed molecular clock as the most optimal model. Haplotypes of $L$. stiedae from Babushkin diverged from a common ancestor of Liobaikalia and closely related species about 1.5 myr. These estimates of the divergence times coincide with the beginning of the significant climatic and geomorphological changes caused reduction of inflow of biogenic elements to the lake (Kachukov et al., 1998; Goldberg et al., 2005). The other Liobaikalia sequences form a clade, whose age is estimated at 0.321.09 my. However haplotypes of $K$. korotnewi and $P$. elata collected in Maloe More clustered with sequences 
of L. stiedae from Koty within Liobaikalia clade ( $<1 \%$ substitutions).

Previously it was shown that intraspecific genetic variation of the other psammobiont baicaliid snail Baicalia carinata exceeds interspecific distances as well as mito-nuclear discordance exists within the genus Baicalia (Peretolchina et al., 2007). Baicalia carinata had two populations boundaries of which partially coincide with big river estuaries. Relation of Liobaikalia intraspecific structuring and geography barriers is not apparent.

\section{Conclusions}

Genetic analysis of cytochrome c oxidase sequences $L$. stiedae disclosed divergent genetic groups represented by local populations. Observed differences between geographically distant populations prove viscous population structure of this species. Phylogenetic relations between different groups of $L$. stiedae and closely related species may indicate the interspecific gene flow or retention of the ancestral polymorphism. Our results highlight the potential problems of relying on a single-locus-marker for delineating baicaliid's species.

\section{Acknowledgments}

This work was supported by the state project of LIN SB RAS No. 0345-2019-0004 (AAAA-A16-116122110060-9) and by Russian Foundation for basic Research No. 19-05-00398.

\section{References}

Drummond A.J., Rambaut A. 2007. BEAST: Bayesian evolutionary analysis by sampling trees. BMC evolutionary biology 7(1): 214. DOI: 10.1186/1471-2148-7-214
Folmer O., Black M., Hoeh W. 1994. DNA primers for amplification of mitochondrial cytochrome c oxidase subunit I from diverse metazoan invertebrates. Molecular Marine Biology and Biotechnology 3(5): 294-299.

Goldberg E.L., Chebykin, E.P., Vorob'eva S.S. et al. 2005. Uranium signals of paleoclimate humidity recorded in sediments of Lake Baikal. Izvestiya AN SSSR [Proceedings of the USSR Academy of Sciences] 400(1-6): 52-56. (in Russian)

Jarman S.N., Ward R.D., Elliott N.G. 2002. Oligonucleotide primers for PCR amplification of coelomate introns. Marine Biotechnology 4(4): 347-355. DOI: 10.1007/ s10126-002-0029-6

Kachukov V., Lykov D., Pevzner L. et al. 1998. A continuous record of climate changes of the last 5 million years stored in the bottom sediments of Lake Baikal. Geologiya i Geofizika [Geology and Geophysics] 39(2): 139-156. (in Russian)

Kovalenkova M.V., Sitnikova T.Y., Sherbakov D.Y. 2015. Genetic and morphological diversification in gastropods of the Baicaliidae family. Russian Journal of Genetics: Applied Research 5(2): 110-117. DOI: 10.1134/S2079059715020045

Nguyen L.T., Schmidt H.A., Von Haeseler A. et al. 2015. IQ-TREE: a fast and effective stochastic algorithm for estimating maximum-likelihood phylogenies. Molecular Biology and Evolution 32(1): 268-274. DOI: 10.1093/ molbev/msu300

Paradis E., Claude J., Strimmer K. 2004. APE: analyses of phylogenetics and evolution in R language. Bioinformatics 20(2): 289-290. DOI: 10.1093/bioinformatics/btg412

Peretolchina T.E., Bukin Y.S., Sitnikova T.Y. et al. 2007. Genetic differentiation of the endemic Baikalian mollusk Baicalia carinata (Mollusca: Caenogastropoda). Russian Journal of Genetics 43(12): 1400-1407. DOI: 10.1134/ S1022795407120095

Wilke T. 2003. Salenthydrobia gen. nov.(Rissooidea: Hydrobiidae): a potential relict of the Messinian salinity crisis. Zoological Journal of the Linnean Society 137(2): 319-336. DOI: 10.1046/j.1096-3642.2003.00049.x

Zubakov D.Y., Sherbakov D.Y., Sitnikova T.Y. 1997. Phylogeny of the endemial Baicaliidae molluscs inferred from partial nucleotide sequences of the $\mathrm{CO} 1$ mitochondrial gene. Molekulyarnaya Biologiya [Molecular Biology] 31(6): 935-939. (in Russian) 